\title{
LONG TERM SUSTAINABLE DEVELOPMENT OF PRAGUE, CZECH REPUBLIC: PROPOSAL FOR CHANGES IN ADMINISTRATIVE DIVISION FOR THE AUTHORIZATION OF NEW CONSTRUCTION
}

\author{
JAROMÍR HAINC, TOMÁŠ HUDEČEK, JIŘÍ ČTYROKÝ, ZUZANA VOJTÍŠKOVÁ \& \\ ALŽBETA GARDOŇOVÁ \\ Institute of Planning and Development, Czech Republic
}

\begin{abstract}
Prague is facing problems with affordable housing. The premise of the study is that in the market driven environment supplied mostly by private development, the length and complexity of the building process (from initial study to building approval) is a key factor. Public investment is lacking while the length of the approval process becomes longer every year in the Czech Republic. The study focuses on Prague, which has the biggest housing market. Roughly four apartments are built per 1,000 inhabitants, which means around 5,000 apartments per year in the city of Prague. The demand for apartments is estimated to be between 6,000 to 8,000 per year. According to the World Bank, the Czech Republic is ranked 156th in terms of time required for building. The length of project preparation from the initial stage to finalization in Prague is very long, taking up to 10 years. Even the OECD shows that as the fragmentation of administration increases, production decreases. The study examines possible ways to improve governance and administration and thus improve the building process to ensure a sustainable city for all. The article will present ways to make planning and building permit procedures more flexible and effective by changing local government responsibilities for various types of planning and building permit procedures. The governance structure will be derived from the several analyses provided by GIS and use a new planning division proposed by the new Land Use Plan of Prague. Research combines expert knowledge, based on deep analyses using data collected at the Institute. Different possible administrative divisions will be justified with possible interactions calculating density, local character, distance to centers, number of permits issued and complexity of the area.

Keywords: governance, building permit process, housing, development trends.
\end{abstract}

\section{INTRODUCTION}

This partial analysis is part of the 1st public tender of the research project of the Technology Agency of the Czech Republic (TAČR) - Improving the systems and processes for permitting new construction in Prague: Housing availability, which analyzes and examines the impact and number of individual plans, their length, complexity and territorial jurisdiction in the capital city of Prague.

For research purposes, the Institute of Planning and Development in Prague (IPR) has access to the PDU database, which contains over $90 \%$ of all land use rulings for Prague. This database provides a very extensive set of data on the course of proceedings for the location of construction, which in many cases is supplemented with subsequent building permit procedures, giving insight into the various phases of the procedures.

Projects are the basic unit monitored. One project represents a set of one or more administrative actions related to this project. For the purposes of research, actions are divided according to manner of use into categories taking into account the divisions of the Metropolitan Plan for negotiation pursuant to Section 50 of the Building Act and according to the categories in PDU. 


\section{ORGANIZATION OF PERMITTING PROCESSES IN PRAGUE BETWEEN 1997 AND 2018}

The length of preparation for housing development projects in Prague depends on the way management processes are implemented according to Czech building laws (especially Building Act No. 183/2006 Coll. [1] and the Administrative Code) and the division of competencies and roles within the City of Prague. The issue of building permits according to Czech law is a relatively complicated process, serving to optimally balance the justified interests of investors with the public interest of the community, as advocated by local government, and more general public interest defended by state administrators. Here, the permitting process is carried out by the state through building authorities. Typically, the building authority is located in municipalities with expanded powers, meaning medium-sized municipalities exercising state administration for several self-governing towns within their natural jurisdiction. The body for appeals is the building authority for the particular region. In Prague, the situation is different because Prague is both self-governing municipality and region, and the manner of implementing the building permitting process depends to a considerable degree on the internal political agreement or decision about which parts of the agenda should be carried out at what level of local government. The ease of establishing a clear, fair and effective system is not helped by the fact that by law the permitting process has two fundamentally different parts: the land use ruling (decision about placement and parameters of the building) and the building permit (decision regarding the technical design of the building). For simple structures both parts can be merged, or the land use ruling can be waived. Since both types of proceedings require a different approach to protect public interest, from a procedural perspective the land use and building permits are organized separately in Prague. The second major consideration is the complex administrative division of Prague, enshrined by law and the statutes of Prague which establish 57 self-governing municipal areas and 22 administrative districts to carry out the state's administrative agenda.

With respect to protecting public interest the key agenda is the land use ruling, because it is here that decisions are made regarding the scope, location and quality of development projects. Until the late 1990s this agenda was centralized at the level of Prague City Hall, with the body for appeals being the Ministry for Regional Development. After 1998, however, due to pressure from the city districts, land use rulings were moved to the level of the 22 administrative districts, so the appellate body became Prague City Hall as the closest higher administrative body.

Building permits, on the other hand, were from the beginning issued at the level of the 22 administrative districts, and the central building authority at City Hall acted as place of appeals and methodological manager.

One of the consequences of this administrative arrangement is that the availability of data regarding the effectiveness and results of both agendas is very different. Despite the decentralization of land use rulings in Prague, City Hall has managed to maintain uniform and nearly complete (approx. 90\%) records of land use rulings and permits issued for development projects throughout Prague. Today these records are an invaluable source of information for much decision-making, including this research. On the other hand, there is no uniform, detailed data on the building permit process, because Prague has never introduced a system to uniformly collect detailed information about building permit procedures and their outcome. If data about building permits is cited in this work, it is always basic data reported for nationwide statistical purposes. 


\section{DATA ANALYSIS OF LAND USE RULINGS}

We begin further considerations of possible organizational changes to the building permit process with a detailed analysis of land use rulings issued in Prague between 1997-2018.

The distribution of projects over the period evaluated is given in Table 1. This analysis only includes projects begun in 1997 or later.

Table 1: Projects with respect to time [7].

\begin{tabular}{|l|c|c|}
\hline Period & Number of projects & \% of projects \\
\hline Projects begun in 1997 or later & 59,889 & 81.70 \\
\hline Projects begun and completed before 1997 & 12,774 & 17.43 \\
\hline Projects with missing data about start or end date & 14 & 0.02 \\
\hline Projects begun before 1997 and ended after it & 624 & 0.85 \\
\hline
\end{tabular}

With respect to project complexity the first thing assessed was the number of administrative actions it involved (Fig. 1). At the same time, the agenda also contains projects not intended to place buildings. The following graph shows two groups of projects (those placing a building and those not). For each group the frequency of projects is displayed by number of actions comprising the project.

Further analysis only considers the group of projects that place a building or buildings.

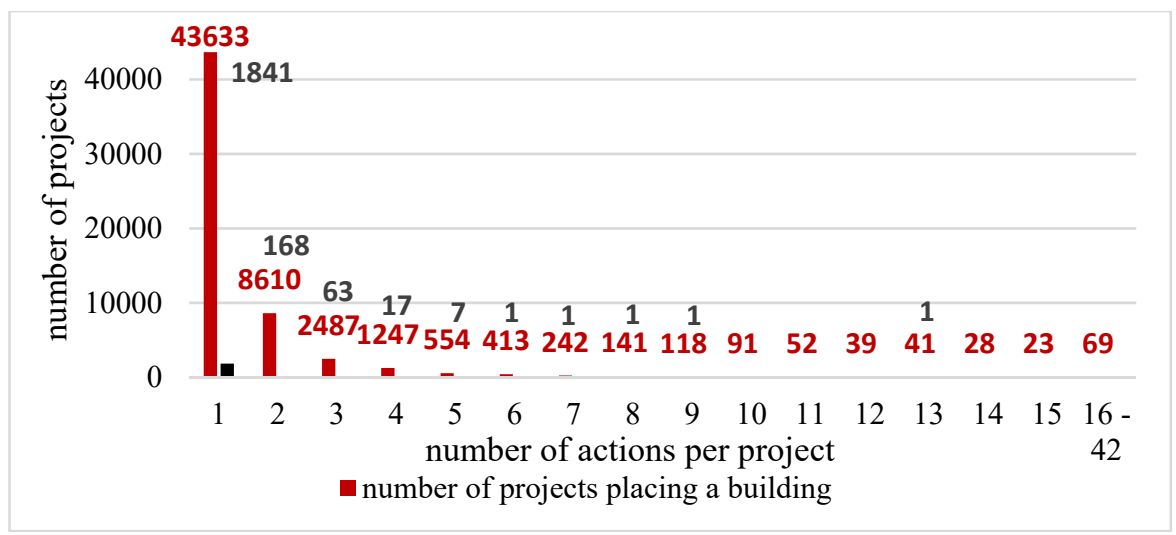

Figure 1: Projects and their complexity according to number of actions for two groups of projects [7].

All data about permitted actions are geographically localized and include available data about permitted use of buildings and capacities (see Fig. 2). This adds another dimension to possible analysis.

As commented in detail in Hainc et al. [2], several events are evident from the graph above. In 2006, a new Building Act was approved, changing certain conditions for building permits. Investors attempted to complete the land use proceedings for as many projects as possible according to the old law to minimize additional project and time costs. This goes hand in hand with the culminating boom of 2006-2007, as seen in Fig. 3. The cooling of the real estate market after 2008 associated with the financial crisis then coincides with a natural decline in projects prepared according to the new Building Act. It is significant that after a 
low point in 2014-2015 Prague was unable to again increase the number of permitted projects with the exception of technical infrastructure projects. The causes of this failure are deeper and related to the gradual change in the decision-making atmosphere of public administrators over roughly the past 10 years.

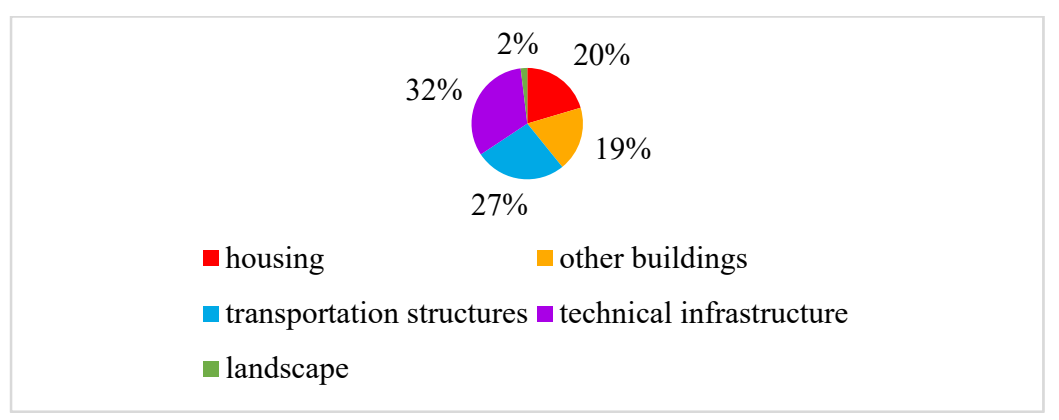

Figure 2: Individual manner of use by percent [7].

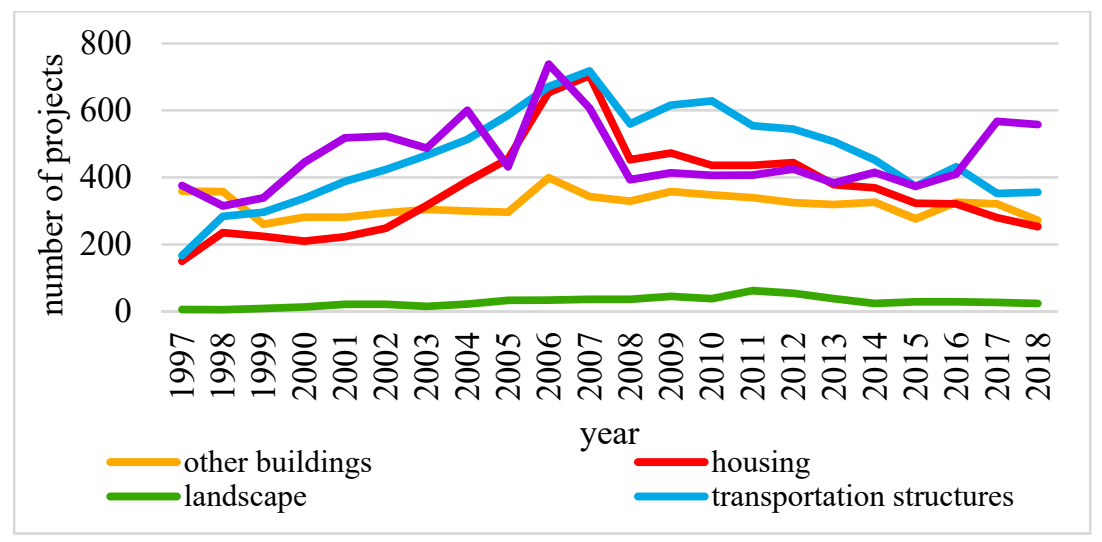

Figure 3: Types of use by year in Prague [7].

The location of permitted projects concentrated in natural development areas of the city, and from 1997-2018 tended to gradually move outward from the city center to the periphery. However, the extensive brownfields in the broader center of Prague were not transformed during this period and will be the focus of development activity in the near future. This is in accordance with the city's policy and its intent to actively reverse the trend of urban sprawl and return major development activity to the built-up areas of the city [3].

From a policy point of view, the failure to restart construction after the financial crisis was most critically felt in the increasing lack of new apartments, which sent apartment prices skyrocketing. Further analysis, therefore, focuses on this market segment. The political reflection of such trend was provided in new strategic plan of the city [4] and its economic amendment [5]. Also, adoption of brand new guidelines for new development in Prague had been adopted as reaction to negative development in both volume and form of housing development [6]. 
Housing projects are grouped according to capacity - according to the number of apartment units (AU) - and separated into three basic groups: up to three AU, up to $33 \mathrm{AU}$ and more than $33 \mathrm{AU}$. As in previous sections of analysis, here we must also work with a group where the number of AU is not listed (separate category). An overview map shows a summary of all projects placing a building since 1997.

The decline in apartment construction is evident in all categories of construction, as seen in Fig. 4. When describing activity in the city, one must realize that the number of projects is not necessarily important, but in certain cases the number of AU may carry greater weight. This difference is evident when comparing both of the graphs below (Figs 5 and 6). The graphs break construction down into 3 categories, indicating whether the project was permitted, suspended, rejected or had some other negative outcome, or whether the status is uncertain (generally an unfinished permitting process).

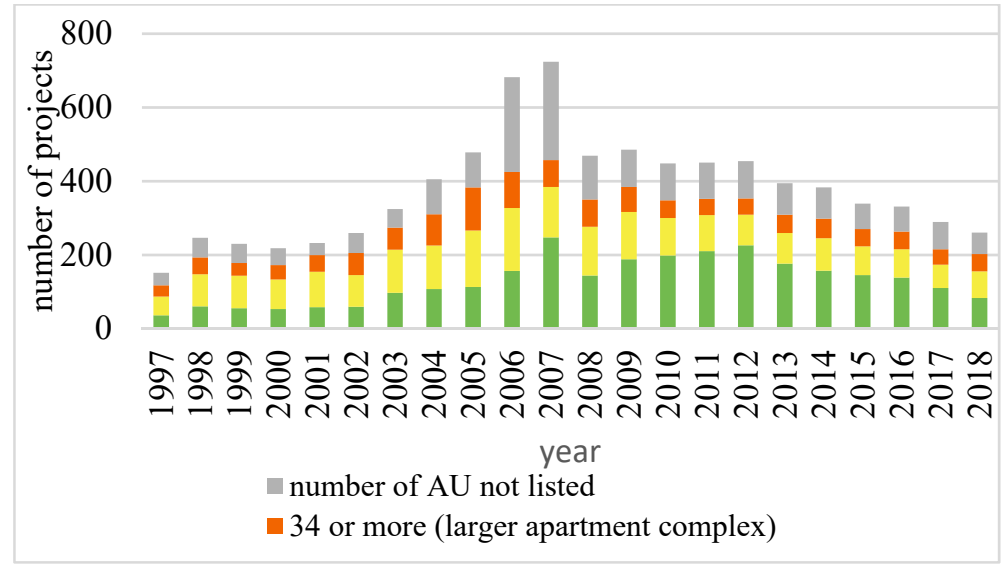

Figure 4: Breakdown of the number of housing AU by year [7].

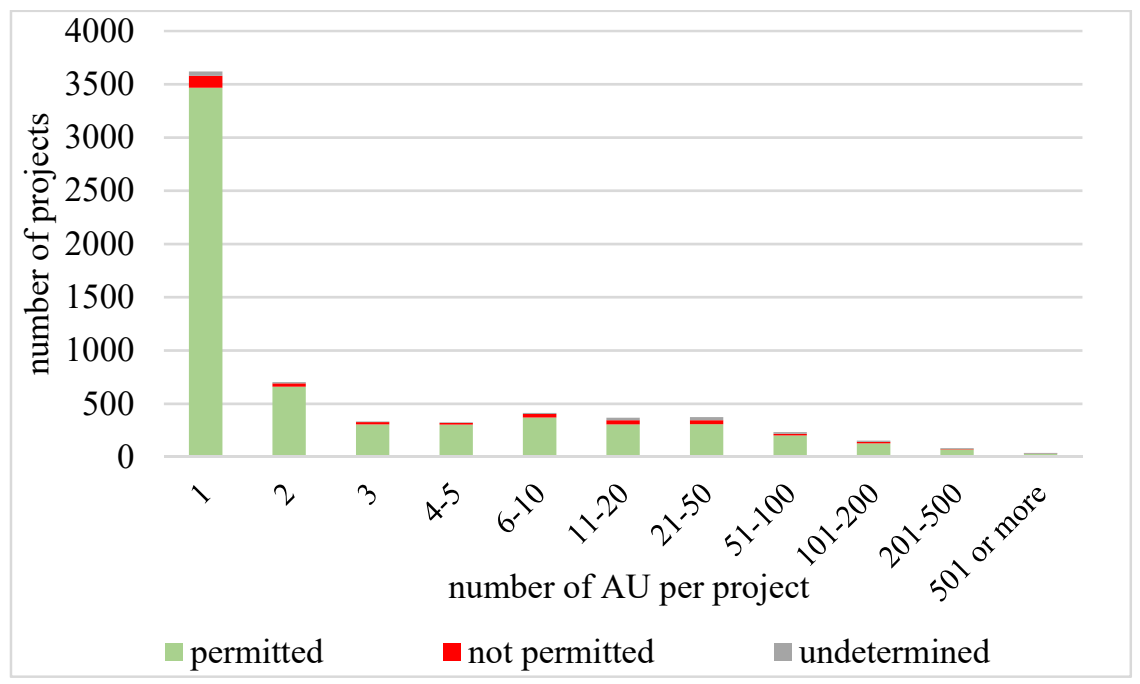

Figure 5: Breakdown of the number of projects in relation to number of AU per project [7]. 


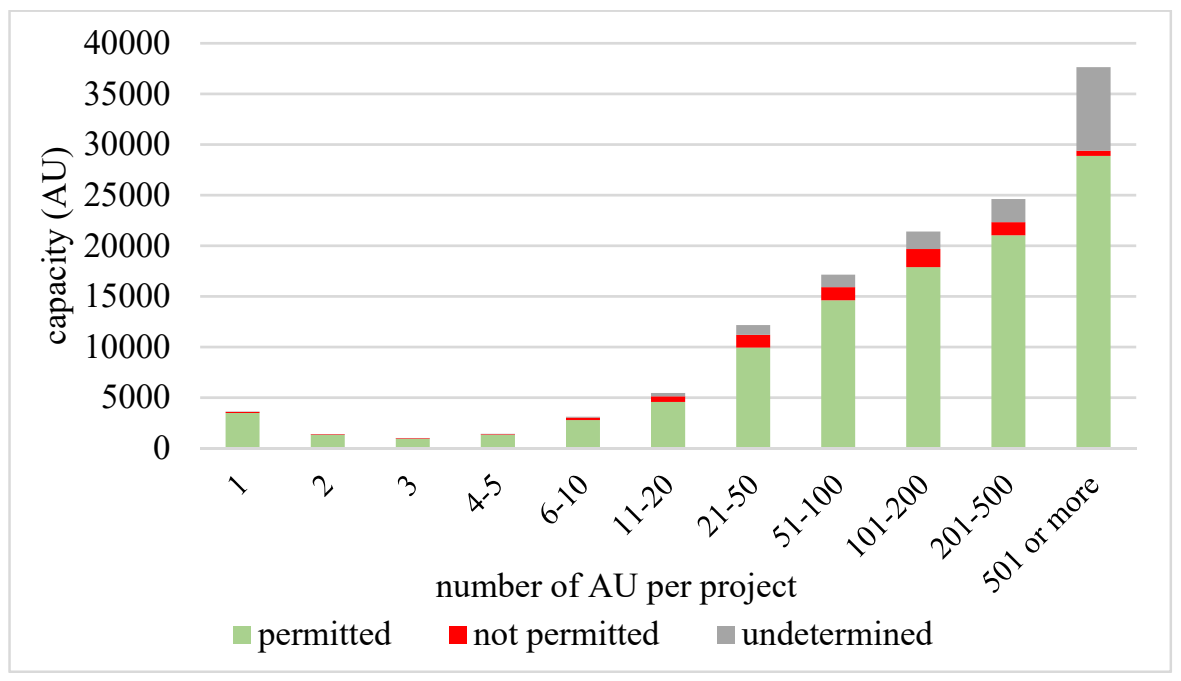

Figure 6: Breakdown of AU by number of AU per project [7].

It is clear from the graphs above that the greatest number of building permits are issued for small projects of one AU, i.e. individual construction. As we see in the text below, the overall capacity of these individual apartments is marginal in relation to the capacity of all permitted apartments. When thinking about how to optimize the building permit process in Prague, this is an extremely important finding. It shows that apartment construction capacity can be improved in Prague by accelerating the building permit process for a relatively small segment of projects: namely, large development projects.

\section{POSSIBLE CHANGES TO THE PROCEDURAL ARRANGEMENT OF THE BUILDING PERMIT PROCESS IN PRAGUE}

When considering other possible bureaucratic arrangements for placing and permitting new construction in Prague we have analyzed actions in individual categories as carried out by the building authorities of individual city districts (family homes, smaller developments apartment complexes (four to $33 \mathrm{AU}$ ), larger developments (34 or more AU).

The analysis shows that part of the period in question cannot be evaluated, since the building authorities of city districts did not work with such actions to sufficient degree. For this reason, we consider the projects begun since 2004, when the current system of building authorities in the 22 city districts was fully in place.

The basic procedural suggestion is to return the building permit process to the city-wide level for select larger projects, thus creating conditions for better and faster negotiations. The creation of a specialized office in one place may result in the positive concentration of specialized know-how to issue permits for larger projects, improve information tools and generally speed up the process significantly. This cannot be achieved by maintaining the segmentation of projects into 22 administrative districts because the share of large projects requiring a specific approach is very small with respect to overall volume of permitted actions.

In contemplating a central building authority, we considered various cutoff limits for the size of residential building projects that would be sent to the central building authority. We came up with three variants for ways that residential projects could be approved by a central 
building authority. These limits were applied to projects from the PDU database from 2004 up to and including 2018, which is why we speak of an analysis. Later project phases may take into account area capacity, existing development, building placement to date and predictions of possible development.

It should be mentioned that the variants presented below deal with only one part, i.e. housing projects with a defined capacity.

4.1 Variant I: The Prague building authority handles permits for projects with 4 or more apartments

In this variant we analyze the possibility of a central building authority handling all building permit applications submitted to city districts containing 4 or more apartment units. This division is based on the definition of a family home, which contains a maximum of 3 apartment units or AU.

Projects for apartment buildings accounted for $29.2 \%$ of all projects submitted to city district building authorities, as seen in Table 2 .

Again, what is important is the capacity of apartment units that is redirected. In this case, $95.1 \%$ of AU would be redirected to the central building authority (see Table 3 ).

Table 2: Number of projects submitted to city districts and share of projects redirected [7].

\begin{tabular}{|l|c|c|}
\hline Workplace & Number of projects & Projects (\%) \\
\hline City district offices - total & 6792 & 100 \\
\hline $\begin{array}{l}\text { Central building authority - } \\
\text { apartment buildings }\end{array}$ & 1978 & 29.2 \\
\hline
\end{tabular}

Table 3: Number of AU in city districts and share of projects redirected [7].

\begin{tabular}{|l|c|c|}
\hline Workplace & Number of AU & AU (\%) \\
\hline City district offices - total & 129,473 & 100 \\
\hline $\begin{array}{l}\text { Central building authority - } \\
\text { apartment buildings }\end{array}$ & 123,435 & 95.1 \\
\hline
\end{tabular}

4.2 Variant II: The Prague building authority handles permits for projects of 34 or more apartments

In this variant we analyze the possibility of a central building authority handling all building permit applications submitted to the city districts containing 34 or more apartment units. Projects for apartment buildings with 34 or more units accounted for $9.5 \%$ of all projects submitted to city district building authorities (see Table 4).

Table 4: Number of projects submitted to city districts and share of projects redirected [7].

\begin{tabular}{|l|c|c|}
\hline Workplace & Number of projects & Projects (\%) \\
\hline City District offices - total & 6,792 & 100 \\
\hline $\begin{array}{l}\text { Central building authority - larger } \\
\text { apartment complexes }\end{array}$ & 646 & 9.5 \\
\hline
\end{tabular}


When looking at AU however, the share of projects redirected is different. In terms of apartment units, this division would place $81 \%$ of $\mathrm{AU}$ under the competence of a central building authority (see Table 5).

Table 5: Number of AU in city districts and share redirected [7].

\begin{tabular}{|l|c|c|}
\hline Workplace & Number of AU & AU (\%) \\
\hline City District offices - total & 129,473 & 100 \\
\hline $\begin{array}{l}\text { Central building authority - larger } \\
\text { apartment complexes }\end{array}$ & 105,428 & 81.3 \\
\hline
\end{tabular}

4.3 Variant III: The Prague building authority handles permits for projects of 57 or more apartments

The third variant calls for dividing projects so that the central building authority handles those containing 57 or more apartment units. This re-directs projects for large apartment complexes. This limit is derived from a gross floor area of $4,000 \mathrm{~m}^{2}$, where the average apartment size is $70 \mathrm{~m}^{2}$.

Projects with 57 or more AC account for $6.59 \%$ of the projects submitted to city districts (see Table 6).

From the perspective of $\mathrm{AU}$, however, the share of projects redirected is different. Calculated as apartment units, this division would re-direct over $73 \%$ of AU to the central building authority (see Table 7).

Table 6: Number of projects submitted to city districts and share redirected [7].

\begin{tabular}{|l|c|c|}
\hline Workplace & Number of projects & Projects (\%) \\
\hline City district offices - total & 6,792 & 100 \\
\hline $\begin{array}{l}\text { Central building authority - larger } \\
\text { apartment complexes }\end{array}$ & 447 & 6.6 \\
\hline
\end{tabular}

Table 7: Number of AU in city districts and share redirected [7].

\begin{tabular}{|l|c|c|}
\hline Workplace & Number of AU & AU (\%) \\
\hline City district offices - total & 129,473 & 100 \\
\hline $\begin{array}{l}\text { Central building authority - large } \\
\text { apartment complexes }\end{array}$ & 96,330 & 73,76 \\
\hline
\end{tabular}

\section{CONCLUSIONS}

When examining the distribution of types of housing (family homes, apartment buildings with up to 33 units, over 34 units and over 57 units) (as seen in Tables 8 and 9), it cannot be said that any city district is dominated by only family homes. At the same time it, it does not appear that the type of permitted buildings changes towards the center with respect to number of units, which could indicate what kind of buildings are found in Prague. Individual types of buildings are diverse and have been examined in detail in individual cadastral areas.

Family homes account for 5 to $15 \%$ of all administrative acts during individual years, and for the entire period examined make up an average of $7 \%$ of all buildings placed. 
Table 8: Number of projects in city districts and share redirected for all variants [7].

\begin{tabular}{|l|c|c|}
\hline Workplace & Number of projects & Actions (\%) \\
\hline City District offices - total & 6,792 & 100 \\
\hline Central building authority - above 4 AU & 1,978 & 29.2 \\
\hline Central building authority - above 34 AU & 646 & 9.5 \\
\hline Central building authority - above 57 AU & 447 & 6.6 \\
\hline
\end{tabular}

Table 9: Number of AU in city districts and share redirected for all variants [7].

\begin{tabular}{|l|c|c|}
\hline Workplace & Number of AU & AU (\%) \\
\hline City District offices - total & 129,473 & 100 \\
\hline Central building authority - above 4 AU & 123,435 & 95.1 \\
\hline Central building authority - above 34 AU & 105,428 & 81.3 \\
\hline Central building authority - above 57 AU & 96,330 & 73.76 \\
\hline
\end{tabular}

It follows from the above that one immediate change that can be made to address the situation in the capital is to create a single "office" to centralize the decision-making for large apartment buildings containing the majority of housing capacity, which may be instrumental in changing the current situation ( as shown in tables and graphs - Fig. 7). From 2004 to 2018 a total of 447 projects in Prague comprised nearly $74 \%$ of all housing capacity permitted. At the same time, this would hypothetically leave a great number of smaller projects with the city districts, depending on the location, size and type of city district.

Fig. 8 shows the context of these changes for individual city districts in terms of number of AU for each variant. The colored depiction illustrates the workload for city districts before introduction of the proposed change.

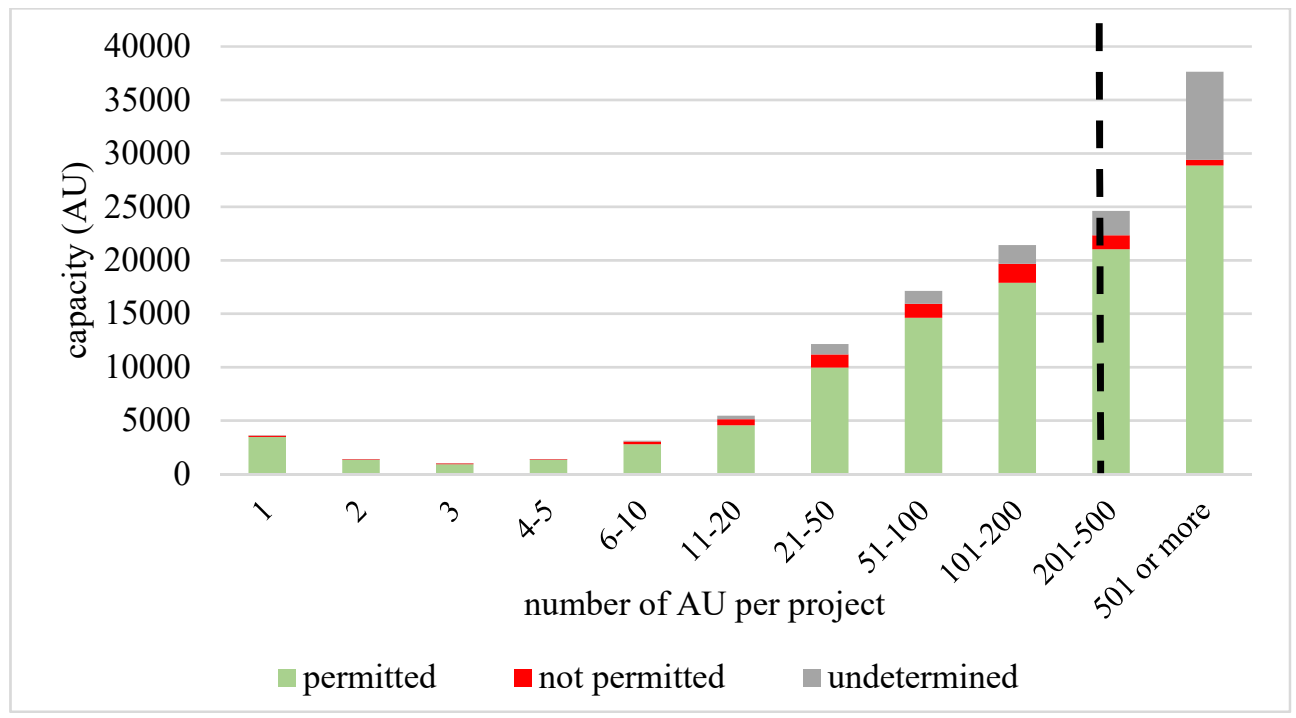

Figure 7: Breakdown of AU according to AU per project [7]. 


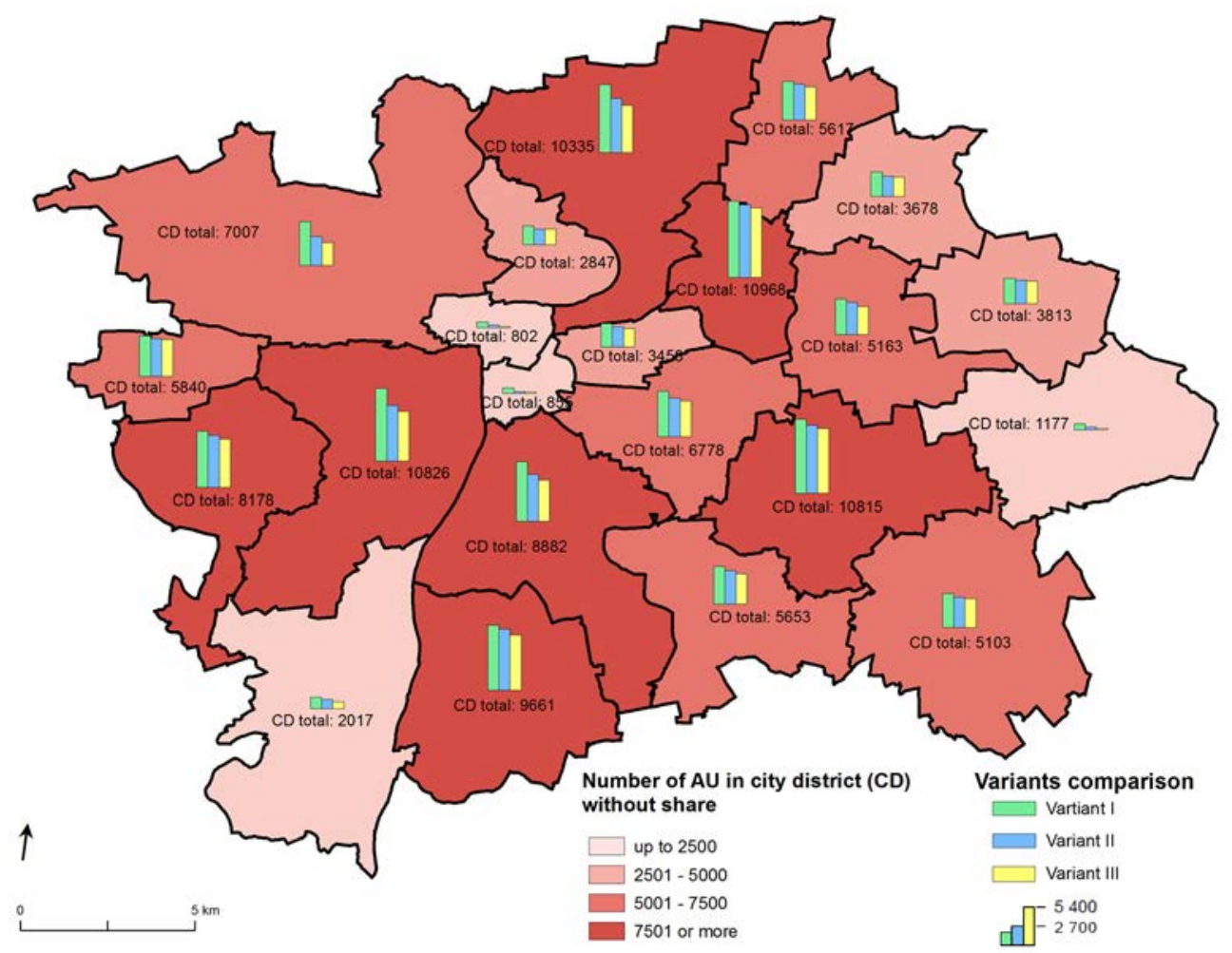

Figure 8: Variants I-III in city districts [7].

On a case-by-case basis we find that for smaller apartment buildings or family homes (often approved as a set of several family homes based on a single land use ruling) there are often objections, appeals, review proceedings of the first instance, annulment of decisions and new proceedings that are once again challenged, leading to appeal proceedings. Also frequent are changes in rulings at the investor's own initiative.

A central building authority can dispose of a greater number of specialists for particular types of buildings and individual phases of the permitting process, and can also concentrate and unify the manner of decision-making in Prague so that the process for complex and extensive buildings is to a certain degree standardized. It must be noted that important large buildings can already be handled centrally upon request of the municipal building department. But this cannot be done for smaller housing projects or family homes, which bog down in appeals or repeated procedures, similar to large construction projects for infrastructure or other large developments, whether for housing or office space.

From the perspective of Prague's development it is essential to reverse the declining numbers of buildings placed and permitted (which is clear from the analyzed data) and further examine possible future demands that will be placed on the permitting process in various parts of the city, taking into account anticipated future capacity in transformation and development areas with the aim of making the best use of capacities for certain segments or areas of the city and accelerating the entire process. 


\section{REFERENCES}

[1] Building Act No. 183/2006 Coll., Czech Republic, 2006

[2] Hainc, J. et al., Zkvalitnění systémů a procesů povolování nové výstavby $v$ Praze: dostupnost bydlení - Analýza, 2019. www.praha.eu/file/2919503/analyza_2019_final.pdf.

[3] Turba, M. et al., Strategický plán hlavního města Prahy, 2. vydání, The City Development Authority: Prague, pp. 131-137, 2008.

[4] Duškov, I. et al., Strategický plán hlavního města Prahy: Návrhová část - aktualizace 2016. Prague Institute of Planning and Development: Prague, 2016.

[5] Makovský, L. et al., Ekonomická udržitelnost města: analýza ekonomických dopad ů Strategického plánu hl. m. Prahy - aktualizace 2016, Prague Institute of Planning and Development: Prague, 2016.

[6] Hnilička, P., et al., Pražské stavební předpisy s aktualizovaným odůvodněním. Prague Institute of Planning and Development: Prague, 2016.

[7] IPR Praha, PDU Database, Prague Institute of Planning and Development: Prague, 2019. 